\section{Accommodating Diverse Learning Styles in an Online Environment}

\section{Lori Mestre, Guest Columnist}

Correspondence concerning this column should be addressed to: Lori Arp, Assistant to the University Librarian, Northwestern University Library, 1970 Campus Drive, Evanston, IL 60208; e-mail: L-arp@northwestern.edu.

Beth S. Woodard is Staff Development and Training Coordinator and Reference Library Head at the University of Illinois at Urbana-Champaign, 300 Library, 1408 West Gregory Drive, Urbana, IL 61801; e-mail:bswoodar@ uiuc.edu.

Lori Mestre is Digital Learning Librarian and Associate Professor of Library Administration at the University of Illinois at Urbana-Champaign.

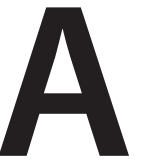

s librarians and instructors strive to provide optimal learning experiences in an online medium, they need to consider the different ways that students learn. Some of the questions that should be asked include: Does one's learning style or preference for a face-to-face environment carry over into an online environment? What learning principles should be considered when designing instructional content for the Web? Are there clues that can be used from what is already known about learning styles for multicultural populations that should be considered as materials are put online? The purpose of this column is to provide some examples from the literature that discuss these questions as they relate to online learning styles, especially for diverse populations.

\section{OVERVIEW OF LEARNING STYLES}

The identification, classification, or definition of learning styles varies widely depending on the perspective of the researcher. Additionally, the term "learning styles" is sometimes used interchangeably with terms such as "thinking styles," "cognitive styles," and "learning modalities." There are numerous theories and opinions on learning styles. While early researchers, such as Kolb, focused on experiential learning, more contemporary researchers have expanded their models to include both psychological and affective dimensions. ${ }^{1}$ James and Gardner suggest that individual learning styles are developed as an outcome of heredity, experience, and current environment, and that a core concept of learning styles is "how people react to their learning environment."2 Dunn cites another commonly accepted definition: "Learning style is a biologically and developmentally determined set of personal characteristics that make the identical instruction effective for some students and ineffective for others."

Four of the common theories and models used to explain how students' learning styles vary are:

- the single learning-style continuum, which includes field dependence and field independence;

- definite learning style, which includes serialist and holist classification;

- situational learning style, which includes surface and deep processing; and

- multidimensional learning style, which includes analytic and intuitive dichotomy. ${ }^{4}$

Other contemporary models, as well as inventories, have also been used to assess learners' modes of thinking. Gardner, for example, asserts that humans have different forms 


\section{INFORMATION LITERACY AND INSTRUCTION}

of intelligences or intellectual strengths, each with its own developmental path. ${ }^{5}$ Research has also shown that many people possess secondary learning styles that can reinforce initial learning. ${ }^{6}$ For this column, Witken's Model and Kolb's Learning Style Inventory will be highlighted, as they provide applicable information regarding cultural distinctions in learning with carryovers to the online environment. ${ }^{\top}$

\section{WHAT DO WE KNOW ABOUT LEARNING STYLES FOR DIVERSE GROUPS?}

There is no one preferred learning style that works for all students or even for any one particular ethnic or cultural group. Not all students from any particular group learn in the same way. In fact, different measurement methods assess different dimensions of learning styles that address such factors as instructional practices, information processing, social-interaction tendencies, and the influence of personality. Librarians need to be aware of cultural differences that influence learning. Cognitive, learning, and motivational styles of many students may be different from those most often expected by teachers and librarians who represent the majority culture. Researchers also suggest that individuals tend to fall into distinct categories related to the manner in which they prefer to learn and, to a large degree, these preferences are culturally identified. ${ }^{8}$

Dunn reviewed dozens of studies of major cultural groups in the United States to assess preferred learning styles. ${ }^{9}$ Although she found that individuals in these groups reflect a diverse array of learning style preferences, she also concluded that certain learning preferences are characteristic of the majority of members of each group. For example, European Americans prefer learning alone, expecting to do things for themselves through self-reliance and competence, whereas Native Americans and Latinos enjoy learning with peers and emphasize cooperation and loyalty. Asian Americans prefer highly structured learning activities, whereas African Americans are more comfortable with minimal structure. African Americans prefer kinesthetic or experiential learning activities more than Asian Americans or European Americans do.

\section{FIELD DEPENDENCE VERSUS FIELD INDEPENDENCE LEARNING THEORY}

Developed in the 1940s, Witkin's theory of field dependence and field independence cognitive styles carries many implications for cross-cultural learning. ${ }^{10}$ It also significantly impacts users' information processing, because the theory describes how well an individual is able to restructure information based on the use of salient cues and field arrangement.

Witkin designed an Embedded Figures Test to determine how well people can deal with a portion of a field separately from the field as a whole. ${ }^{11}$ Field independence and field dependence as defined by Witkin and others are related to those characteristics of individual functioning that surface in social, intellectual, and perceptual domains of human behavior. For example, field-independent individuals per- ceive objects as separate from the field; abstract figures from a field; impose personal structures on the environment; set self-defined goals; work alone; choose to deal with abstract subject matter; are socially detached and rely on their own values; and are self-reinforcing. Field independents tend to be more self-directed and better able to make sense of unstructured material. Due to their narrow focus and ability to screen, field independents can usually process information more efficiently, but may miss the social context that their field-dependent peers more readily perceive.

In contrast, field-dependent people tend to rely on the field for clues about an object; prefer a structure provided by the environment; experience the environment more globally; are interested in people; use externally defined goals; receive reinforcement from others; focus on socially oriented subject matter; and prefer to work with others. Field dependents tend to learn better in a social setting (for example, class discussion, group work) and where direction and structured material are provided for them. They tend to specialize in work and study requiring interaction with people.

Findings by Anderson and Adams concluded that white and Asian American men tend to be field-independent learners who are parts-specific, can isolate facts as needed, are rather linear in their thinking and problem solving, and tend to test well. ${ }^{12}$ On the other hand, white females, African Americans, Native Americans, and Latinos of both sexes tend to be field-dependent learners; must see the big picture; are able to see details only in relation to the whole; seek to find personal relevance in the task at hand; and require that some sort of personal relationship be established between the instructor and the student. Field-independent learners may work well in a teacher-centered classroom that encourages competition and that allows them to develop their own strategies in nonsocial problem-solving domains, whereas field-dependent learners may prefer a cooperative learning environment that encourages peer interaction and support and that pays more attention to the social context in which tasks are framed. ${ }^{13}$ Field-dependent learners may also prefer to interact with the teacher, and tend to learn better when some structure, mediation plans, or strategy is provided.

Kerka stated that field-independent learners are more efficient in search-and-navigation tasks, whereas fielddependent learners are more likely to feel lost and disoriented in computer-mediated or hypermedia environments. ${ }^{14}$ Ogle compared field dependents' and independents' performance on a task of recall. ${ }^{15}$ The content was presented through two different treatments: a virtual environment and static images. A significant interaction was found between field dependence and treatment type favoring field independents in the virtualenvironment treatment. DeTure found that students who are more field independent not only have higher self-efficacy when using online technologies, but also have higher confidence levels with online technologies. ${ }^{16}$ The research using this model suggests that those who are field dependent (for example, large proportions of Latinos, African Americans, and Native Americans) may have a disadvantage in an online environment if geared to the dominant culture. 


\section{KOLB'S LEARNING STYLE INVENTORY}

A number of studies have applied Kolb's theory to investigate how learning styles affect e-learning and hypermedia learning (with specific considerations for diverse groups), and most of them indicate that learning styles play a key role in learning. ${ }^{17}$ Other studies on relationships between learning style and e-learning have been done on college- and graduate-level students, and citations to them can be found in the references. ${ }^{18}$

Kolb's model conceptualizes the learning process as a four-stage cycle including:

- reflective observation or "learning by watching and listening, carefully observing before making judgments, viewing issues from different perspectives, looking for meaning of things";

- abstract conceptualization, or focusing on using logic, ideas, and concepts;

- active experimentation or "learning by doing, ability to get things done, risk-taking, influencing people and events through action"; and

- concrete experience, or using experiences and real situations that are personally and immediately relevant to the individual. It emphasizes feeling, as opposed to thinking.

By pairing preferences for how experiences are perceived (theoretical or pragmatic) and how these experiences are transferred into knowledge (doing or reflective), Kolb identifies four different learning styles:

- Assimilator $=$ Reflective/Theoretical一(Asian Americans tend to fit into this category.) This category includes individuals who are best at understanding a wide range of information and putting it into concise, logical form. They are less focused on social aspects of learning and more interested in abstract conceptualization and reflective observations.

- Converger $=$ Doer/Theoretical - This category includes individuals who can take ideas and turn them into concrete situations. They use abstract conceptualization and active experimentation to learn.

- Diverger $=$ Processor $/$ Reflector - This category includes individuals who are strong on imagination and can view a concrete situation from a variety of perspectives. They use reflective observation and processing to learn.

- Accomodator $=$ Processor/Doer-(Latinos, white females, African Americans, and Native Americans tend to fit in this category.) This category includes individuals who use concrete experiences, or attempt to make any situation concrete. They are good adaptors.

\section{ONLINE SUCCESS CHARACTERISTICS}

Of the four learning styles described by Kolb, Accommodators seem to be the most at risk in online-learning environments. Researchers are finding that Accommodators are the least likely to succeed in an online-learning environment that is abstract and reflective. ${ }^{19}$ Rourke commented that:

The Accommodators have an intuitive, active approach to perceiving and processing information. They perform best in environments in which concrete, practical information is presented through interaction with peers and instructors. They process information best when they can actively apply this information to authentic situations. ${ }^{20}$

Moeller also found that "the most dominant learning style in the nontraditional learning environment was the accommodator style." ${ }^{21}$ In other studies, students with assimilating and accommodating learning styles demonstrated significantly more agreeable attitudes toward varied aspects of networkbased instruction than students with converging and diverging learning styles. ${ }^{22}$ When creating online-learning environments, it is critical that the needs of Accommodators be met via personalized learning with hands-on experiences. Kolb's study remains one of the most significant for those working with learning styles. As others research learning in the online environment, they have used Kolb's work as a starting point for their online research. Honey and Mumford's work is one example of this.

Honey and Mumford developed a modified version of Kolb's learning style inventory, which turns the Doer, Reflector, Theoretical, and Processor preferences into learning styles called Activists, Reflectors, Theorists, and Pragmatists. ${ }^{23}$ Of the four types, Reflectors and Theorists tend to do best in online environments, partly because an online environment might provide them more time to think about their tasks. The remaining groups, Activists and Pragmatists, also have various characteristics that benefit from online instruction, but do well in face-to-face instruction as well. Activists like to be involved in new experiences and problem solving. They enjoy doing things and tend to act first and consider the implications afterwards. They like working with others, but prefer being leaders where they can direct the course. Pragmatists are keen to try things out. They want concepts that can be applied to their job or life. They tend to be impatient with lengthy discussions and are practical and down to earth. They learn best when they have the chance to try out techniques with feedback (for example, role playing), are shown techniques with obvious advantages (for example, saving time), and are shown a model they can copy.

Reflectors like to stand back and look at a situation from different perspectives. They like to collect data and think about them carefully before coming to any conclusions. They enjoy observing others and will listen to their views before offering their own. Branford concluded that the Reflector learning style is much more prevalent among Asian students who like to think about their responses; the affordance of an online environment allowed Asian students a chance to view materials, process them, and then complete them at their pace. ${ }^{24}$ Use of tutorials and materials posted in advance was advantageous for these students' styles of learning. Downing and Chim suggest that, given the reported prevalence of this 


\section{INFORMATION LITERACY AND INSTRUCTION}

style of learning among Asian students, this is an important consideration when designing programs for Asian students, particularly in Western universities. ${ }^{25}$

Other studies have found that, when using Honey and Mumford's model, those classified as Theorists also tend to do well in an online environment. ${ }^{26}$ Theorists tend to think problems through in a vertical, step-by-step, and logical way. They like to analyze and synthesize and tend to be detached, analytical, and dedicated to rational objectivity rather than relying on subjectivity. This is their mental set, and they rigidly reject anything that doesn't fit with it. They tend to be perfectionists who will not rest easy until things are tidy and fit into their rational scheme. They need time to explore links between ideas and structure in their thinking. These individuals often feel frustrated and find it difficult to speak up in the traditional classroom. These studies suggested that online learning is a more effective means of teaching students who fit within this learning style.

\section{NEW AND EMERGING TYPES OF LEARNERS}

In addition to what is commonly known about learning styles, research is beginning to appear that discusses learning styles of some emerging groups that haven't been widely studied before. Two of these groups are the Global Learners and the Millennials.

\section{Global Learners}

The literature suggests that Global Learners prefer to follow an almost random sequence through material. ${ }^{27}$ They are likely to benefit from exploratory links that provide practical examples of course material to help them make connections. They are also likely to benefit from creative activities that allow them to identify how the pieces of information fit together. The Internet appears to provide the ideal environment for Global Learners, allowing them to explore a course in any sequence they want, although they still may look for connections between topics and sources of information provided.

Instructional designers preparing for a global audience should also design curricula that are understandable to secondlanguage learners. There are more English as a Second Language (ESL) learners in the world today than there are native English speakers. ${ }^{28}$ It is important to create materials that are culturally neutral and in simple English. This requires using a simple sentence structure and avoiding slang, colloquialisms, local humor, and local insider examples whenever possible. However, it is important to use culturally relevant examples, not just examples from the mainstream population.

\section{Millennials}

Another group that is currently a focus of studies related to online-learning styles is the Millennials (also referred to as Generation Y, the Net Generation, Echo Boomers, and the Google Generation). The Millennials are the most ethnically diverse generation in U.S. history and have been immersed in the digital environment from a very young age. They are used to multitasking, tend to be visual learners, and benefit from lots of tactile experiences. What seems evident from the current research is that Millennials prefer to do what is of personal interest to them and are motivated by authentic tasks or self-selected tasks (that is, is it relevant, and do I care?). They prefer a lot of interactivity, the use of mobile tools, and social networking. Therefore, providing them interactive multimedia that allows them to choose their topics and customize their paths online may motivate and engage them more. ${ }^{29}$

\section{ENHANCING TEACHING FOR THE ONLINE ENVIRONMENT}

Most current online situations best serve the students who function well in a logical, text-based, passive environment. But many students require more personalized attention in an interactive environment. To provide equivalent services to all students, it is essential that special attention be paid to developing resources that support students who require this more personalized, interactive learning environment. Tanno noted that for some students, "university success . . . is correlated with personal, consistent, face-to-face interaction with faculty, staff, and students"; the trend toward Web-based education reduces the likelihood of this interaction. ${ }^{30}$ When a diversity of learning and collaborative approaches is offered, all students are enabled to choose a learning environment that best suits their learning style (possibly multiple environments). Following are some suggestions of how to enhance and design Web pages, tutorials, and online courses to better accommodate various learning styles.

\section{Web Design Suggestions}

To accommodate a broad range of learning styles, online Web and course designers need to move beyond text-based interactions and include visual or kinesthetic modalities, as well as intuition and thinking exercises. ${ }^{31}$

For instance, to provide a more interactive Web environment, librarians at Lesley College retooled their Web pages to accommodate learners. Previously, instruction on their pages was passive, inviting students to read and click, but not necessarily to interact. Understanding that Accommodators may find this an alien learning environment, the librarians worked to create interaction by challenging students to think about an issue, respond to a question, and get immediate feedback. They also wanted to provide more theory for the Assimilators and Convergers. They personalized such pages as the Ask-a-Librarian page and other service pages with photos of librarians who deliver the service, and created welcome notes to students and to those with disabilities. Their goal was to provide a more personal connection, which is thought to be helpful particularly to Accommodators, who prefer to learn from people rather than objects. ${ }^{32}$

The Web may also present problems for sequential and auditory learners. While the Web can accommodate the needs of textual learners, it reduces face-to-face communica- 
tion. It thus may deprive participants of body language, tone of voice, and gesture, which may result in a loss of context. The Web may also present problems for those who prefer not to read large quantities of text. If students are sequential, active, visual learners, Web designers could provide clear pathways through the material, include interactive testing and online exercises, and ensure that plenty of diagrams and photographs are provided to supplement the necessary predominance of text.

While the evidence suggests that there has been little change in the learning styles of the majority of students during the past few decades, employing a variety of teaching methods is an effective strategy for accommodating those who do not fit the dominant profile. Designers who are sensitive to these propensities and preferences would do well to take advantage of the variety of Internet delivery mechanisms available. ${ }^{33}$ The following section will highlight some suggestions from the literature for augmenting tutorials and then Web pages, in general, to accommodate different learners.

\section{Tutorial Design}

Sequenced-learning strategies can be used as tools to accommodate these differences. Tutorials can include concept mapping, mental imagery, interactive quizzes, or self-correcting quizzes and exercises as learning strategies. They could also be structured to allow students to choose a topic of personal interest (even a self-directed, active approach where learners are given the choice of selecting life events and experiences as the basis of learning) and control their progress and get immediate feedback in a friendly, supportive manner. ${ }^{34}$ There should be a combination of text and images, and preferably multimedia. A good example of a student-centered approach would be to create programming to allow students to control their progress (while providing step-by-step instructions as needed). Activities should be integrated throughout the tutorial.

\section{General Suggestions}

Librarians can supplement online instruction by using such techniques as problem-based and active learning, case studies and simulations, structured communication (such as fillin forms), and reflective activities. For the nontextual visual learner, one should add multiple sensory options such as animations, hands-on simulations, video clips, charts, pictures, graphic illustrations, and diagrams, as well as audio files for auditory learners. Various authors also recommend presenting material from multiple perspectives, building links among concepts to facilitate the synthesizing of information..$^{35}$

\section{CONCLUSION}

Because of changes in society, students are becoming increasingly diverse. Therefore, our courses and Web pages must become more flexible and creative in the types of communication, interactions, and learning materials used. By combining learning strategies, learners are afforded the opportunity to learn via an assortment of styles and to apply their own blend of intelligences. This will hopefully create a positive learning environment that will in turn create more engagement with the material being presented, thus helping the student work toward competency in library research skills. ${ }^{36}$

Currently, most online situations best serve students who function well in a logical, text-based, passive environment. If equivalent services are to be provided to all students, it is essential that special attention be paid to developing resources that support students who require a more personalized, interactive learning environment. When a diversity of learning approaches is offered, all students are enabled to choose from among different environments to make learning most efficient.

\section{References and Notes}

1. David A. Kolb, Learning Style Inventory: Technical Manual (Boston, Mass.: McBer, 1985. First published in 1976).

2. Wayne B. James and Daniel L. Gardner, "Learning Styles: Implications for Distance Learning," New Directions for Adult and Continuing Education 67 (Fall 1995): 20.

3. Rita Dunn, "Capitalizing On College Students' Learning Styles: Theory, Practice, and Research," in Practical Approaches to Using Learning Styles in Higher Education (Westport, Conn.: Bergin \& Garvey, 2000), 9.

4. Henry Witkin et al., "Field-Dependent and Field-Independent Cognitive Styles and Their Educational Implications," Review of Educational Research 47, no. 1 (Winter 1977): 1-64; George Pask, "Styles and Strategies of Learning," British Journal of Educational Psychology 46, no. 2 (1976): 128-48.

5. Howard Gardner, Intelligence Reframed: Multiple Intelligences for the 21st Century (New York: Basic Books, 1999); Howard Gardner, Frames of Mind: The Theory of Multiple Intelligences, 10th ed. (New York: BasicBooks, 1993).

6. Stephen Denig, "Multiple Intelligences and Learning Styles: Two Complementary Dimensions," Teachers College Record 106, no. 1 (2004): 96-111.

7. Henry Witkin, "Individual Difference in Ease of Perception of Embedded Figures," Journal of Personality 19, no. 1 (1950): 1-15; Kolb, Learning Style Inventory.

8. Joanne P. H. Bentley, "Intercultural Internet-Based Learning: Know Your Audience and What It Values," Educational Technology Research and Development 53, no. 2 (2005): 117-27; Dunn, Practical Approaches To Using Learning Styles, 3-18; Shirley A. Griggs and Rita Dunn, Hispanic-American Students and Learning Style (Urbana, Ill.: ERIC Clearinghouse on Elementary and Early Childhood Education, ERIC Document Reproduction Service, ED 393 607, 1996); James A. Anderson and Maurianne Anderson, "Acknowledging the Learning Styles of Diverse Student Populations: Implications for Instructional Design," New Directions for Teaching and Learning 49 (Spring 1992): 19-33; Charles S. Claxton, "Learning Styles, Minority Students, and Effective Education," Journal of Developmental Education 14, no. 1 (Fall 1990): 6-8, 35; Sonia Bodi, "Teaching Effectiveness and Bibliographic Instruction: The Relevance of Learning Styles," College \& Research Libraries 54 (Mar. 1990): 113-19; Kevin Cushner, "Preparing Teachers for Intercultural Context," in Improving Intercultural Interactions: Modules for Cross-Cultural Training Programs (Thousand Oaks, Calif: Sage, 1990).

9. Dunn, "Capitalizing on College Students' Learning Styles;" Virginia Zanger, Exploración Intercultural-Una Guía para el Estudiante (Rowley, Mass.: Newbury House Pubs., 1984).

10. Sherry Chen et al., "A Flexible Interface Design for Web Directories to Accommodate Different Cognitive Styles," Journal of the American Society for Information Science and Technology 56, no. 1 (Jan. 2005): 70-83; Huey-Wen Chou and Tsung-Bin Wang, "The Influence of Learning Style and Training Method on Self-Efficacy 


\section{INFORMATION LITERACY AND INSTRUCTION}

and Learning Performance in WWW Homepage Design Training," International Journal of Information Management 20, no. 6 (2000): 455-72; Herman G. Weller, Judy Repman, and Gene E. Rooze, "The Relationship of Learning, Behavior, and Cognitive Styles in Hypermedia-Based Instruction: Implications for Design of HBI," Computers in the School 10, no. 3/4 (1994): 401-20.

11. Witkin, "Individual Difference in Ease of Perception of Embedded Figures."

12. Anderson and Anderson, "Acknowledging the Learning Styles of Diverse Student Pupulations."

13. Carol Smith, Haeryon Kim, and James M. Bernstein, "Because it's Time: Teaching Computer-Mediated Communication," (Montreal, Que.: A Paper Presented to Communications Technology and Policy Interest Group, ERIC Document Reproduction Service, ED 352 681, 1992).

14. Sandra Kerka, Learning Styles and Electronic Information: Trends and Issues Alert (Columbus, Ohio: ERIC Clearinghouse on Adult, Career, and Vocational Education, ERIC Documentation Reproduction Service, ED 420 788, 1998).

15. Jeffrey Todd Ogle, "The Effects of Virtual Environments on Recall in Participants of Differing Levels of Field Dependence" (Ph.D. diss., Virginia Polytechnic and State Univ., 2002).

16. Monica DeTure, "Cognitive Style and Self-Efficacy: Predicting Student Success in Online Distance Education," American Journal of Distance Education 18, no. 1 (Mar., 2004): 21-38.

17. Alice Kolb and David Kolb, Experiential Learning Theory Bibliography (Cleveland, Ohio: Experience Based Learning Systems, 1993).

18. Cheryl Jones, Carla Reichard, and Kouider Mokhtari, "Are Student Learning Styles Discipline Specific?" Community College Journal of Research and Practice 27, no. 5 (2003): 363-75; Steve Terrell, "The Effect of Learning Style on Doctoral Course Completion in a WebBased Learning Environment," Internet and Higher Education 5, no. 4 (2002): 345-52; Laurie Dringus and Steve Terrell, "The Framework for DIRECTED Online Learning Environments," Journal of the Internet in Education 2, no. 1 (1999): 55-67; Karen Rasmussen and Gayle Davidson-Shivers, "Hypermedia and Learning Styles: Can Performance Be Influenced?" Journal of Education Multimedia and Hypermedia 7, no. 4 (1998): 291-308.

19. Carole Simpson and Yunfei Du, "Effects of Learning Styles and Class Participation on Students' Enjoyment Level in Distributed Learning Environments," Journal of Education for Library and Information Science 45 (Spring 2004): 123-36; Katherine Holmes and Cynthia Brown, "Meeting Adult Learners, Wherever They May Be: If It's Thursday, It Must Be Thermopolis," in Teaching The New Library to Today's Users: Reaching International, Minority, Senior Citizens, Gay/Lesbian, First-Generation, At-Risk, Graduate and Returning Students, and Distance Learners, eds. Trudy E. Jacobson and Helene C. Williams (New York: Neal-Schuman, 2000); Liam M. Rourke and Linda Lysynchuk, The Influence of Learning Style on Achievement in Hypertext (New Orleans: The Annual Meeting of the American Educational Research Association, ERIC Document Reproduction Service, ED 466 102, 2000).

20. Rourke and Lysynchuk, The Influence of Learning Style on Achievement in Hypertext, 9

21. Jean S. Moeller, "A Research Study to Discover Temperament Types, Communication Styles, and Learning Styles of Adult Learners in Nontraditional and Online Learning Environments," paper presented at Honoring Our Roots and Branches ... Our History and Future. Proceedings of the Annual Midwest Research to Practice Conference in Adult, Continuing, and Community Education, Madison, Wisc., 2000.

22. Pat Federico, "Learning Styles and Student Attitudes toward Various Aspects of Network-based Instruction," Computers in Human Behavior 16, no. 4 (2000): 359-79; Jonathon L. Ross, "On-Line but Off Course: A Wish List for Distance Educators," International Electronic Journal for Leadership in Learning 2 (May 12, 1998, www .ucalgary.ca/ iejl1/volume2/Ross2_3.html (accessed Aug. 1, 2006).
23. Peter Honey and Alan Mumford, The Learning Styles Questionnaire (Maidenhead, Berkshire, U.K.: Peter Honey Pubs., 2000); Peter Honey and Alan Mumford, The Manual Of Learning Opportunities. (Maidenhead, Berkshire, U.K.: Peter Honey Pubs., 1986).

24. Paul Barron, "Providing a More Successful Education Experience for Asian Hospitality Management Students Studying in Australia: A Focus on Teaching and Learning Styles," Journal of Teaching in Travel and Tourism 2, no. 2 (2002): 63-88.

25. Kevin Downing and Tat Mei Chim, "Reflectors as Online Extraverts?" Educational Studies 30, no. 3 (2004): 265-76.

26. Terrell, "The Effect of Learning Style on Doctoral Course Completion in a Web-based Learning Environment"; Charlotte Neuhauser, "Learning Style and Effectiveness of Online and Face-To-Face Instruction," American Journal of Distance Education 16, no. 2 (2002): 99-113; William E. Souder, "The Effectiveness of Traditional versus Satellite Delivery in Three Management of Technology Master's Degree Programs," The American Journal of Distance Education 7, no. 1 (1993): 37-53.

27. Barbara Solomon and Richard Felder, "Learning Styles and Strategies," in Resources in Science and Engineering Education (North Carolina State Univ., 2000), www2.ncsu.edu/unity/ lockers/users/ f/felder/public/ILSdir/styles.htm (accessed Aug. 3, 2006); Barbara Solomon and Richard Felder, "Index of Learning Styles Questionnaire," (NCSU, 1999) www.engr.ncsu.edu/learningstyles/ilsweb .html (accessed Aug. 3, 2006).

28. May Ying Chau, "Connecting Learning Styles and Multiple Intelligences Theories through Learning Strategies: An Online Tutorial for Library Instruction," LIBRES 16, no. 1 (Mar. 2006): 513-14; David Ward, "English Plus," Language Magazine 3, no. 7 (2004): 6; Anna Mauranen, "The Corpus of English as Lingua Franca in Academic Settings," TESOL Quarterly 37, no. 3 (Autumn 2003): 513-14.

29. Francis J. Harris, I Found It on the Internet: Coming of Age Online (Chicago: ALA, 2005); Wendy Holliday and Qin Li, "Understanding the Millennials: Updating Our Knowledge about Students," Reference Services Review 32, no. 4 (2004): 356-66; Kate Manual, "Teaching Information Literacy to Generation Y at California State University, Hayward," Journal of Library Administration 36, no. 1/2 (2002): 195-217; Neil Howe and William Strauss, Millennials Rising: The Next Great Generation (New York: Vintage, 2000).

30. Dolores V. Tanno, "When Education, Media, and Technology Converge, What Do Latino/A Students Gain?" Journal of Latinos and Education 2, no. 1 (2003): 42

31. Neuhauser, "Learning Style and Effectiveness of Online and FaceTo-Face Instruction."

32. Katherine H. Holmes, "A Kaleidoscope of Learning Styles: Instructional Supports that Meet the Diverse Needs of Distant Learners." Journal of Library Administration, 37, no. 3/4 (2002): 367-78.

33. Denice Adkins, Christopher Brown-Syed, and Hui-Hsien Tsai, "LIS Student Learning Styles and Web-Based Instruction Methods," Journal of Library E Information Services in Distance Learning 2, no. 1 (2005): 5-26.

34. Suggestions of tutorials that motivate multiple learners (suggested by Holmes, "A Kaleidoscope of Learning Styles": Blais Tutorial-Libraries of Claremont Colleges, voxlibris.claremont.edu/ research/tutorials.html (accessed Aug. 3, 2006); MAGS (Magician) Tutorial (Univ. of California-Riverside), library.ucr.edu/MAGS/ Welcome.html (accessed Aug. 3, 2006); TILT (Univ. of Texas), tilt.lib .utsystem.edu/ (accessed Aug. 3, 2006).

35. Dusti Howell, "Elements of Effective E-Learning: Three Design Methods to Minimize Side Effects of Online Courses," College Teaching 49, no. 3 (summer 2001): 87-90; Holmes and Brown, "Meeting Adult Learners, Wherever They May Be," in Teaching the New Library to Today's Users, eds. Trudy E. Jacobson and Helene C. Williams.

36. Chau, "Connecting Learning Styles and Multiple Intelligences Theories." 